\title{
New Evidence on the Origins of the Latin Mirror of Simple Souls from a Forgotten Paduan Manuscript ${ }^{*}$
}

\author{
Justine L. Trombley
}

This article examines an overlooked fifteenth-century document which attacks and refutes thirty-five extracts from a Latin copy of the condemned fourteenth-century work The Mirror of Simple Souls. It gives an overview of the document's origins, provenance, and contents, and then discusses how certain omissions in the text's source citations have crucial implications for more firmly establishing the date of origin for the Latin translation of the Mirror.

Keywords: The Mirror of Simple Souls; Marguerite Porete; medieval heresy; Latin translation; manuscripts

The fourteenth-century mystical work The Mirror of Simple Souls (Le Mirouer des Simples Âmes/Speculum Simplicium Animarum) has long been noted for its resiliency. Though it was twice condemned as heretical, and its author, Marguerite Porete, was burned at the stake in Paris in 1310 for circulating it, the Mirror escaped Marguerite's fiery fate and went on to circulate anonymously in Latin, Middle English, Italian, and Middle French. ${ }^{1}$ Its manuscript corpus demonstrates that it was translated, copied, read, and valued by a number of different readers, its original condemnation apparently forgotten. ${ }^{2}$ But there is another, less-examined

\footnotetext{
* This article was first given as a paper at the Annual Meeting of the Medieval Academy of America, held at the University of Notre Dame in March 2015. It formed part of the panel Fresh Findings From Missed

Manuscripts: Margherita Colonna, Joachim of Fiore, and Marguerite Porete, organised by Sean Field. I would like to thank Prof. Field for inviting me to participate in the panel. I am very grateful to the staff of the Special Collections department at the Biblioteca universitaria in Padua for allowing me access to their collections and providing me with photographic reproductions. I thank Frances Andrews, Chris Given-Wilson, John Arnold, Julian Luxford, Sean Field, Robert Lerner, Pablo Garcia-Acosta, and Zan Kocher for their helpful comments, criticisms, and encouragement throughout the development of this article. I also thank the anonymous reviewers for their helpful comments and suggestions. The majority of research for this article was carried out as part of my doctoral work at the St Andrews Institute of Mediaeval Studies, University of St Andrews.

${ }^{1}$ The trial and execution of Marguerite Porete has been documented in Sean L. Field, The Beguine, the Angel, and the Inquisitor: The Trials of Marguerite Porete and Guiard of Cressonessart (Indiana: University of Notre Dame Press, 2012) [Hereafter Field, BAI], with further considerations in Field, 'William of Paris's Inquisitions Against Marguerite Porete and Her Book', in Marguerite Porete et le Miroir des simples âmes: Perspectives historiques, philosophique, et littéraires, ed. Sean L. Field, Robert E. Lerner, and Sylvain Piron (Paris: Libraire Philosophique J. Vrin, 2013), 233-247 [Hereafter Marguerite et le Miroir]. For an additional perspective on William of Paris's direction of the trial, see Henry Ansgar Kelly, 'Inquisitorial Deviations and Cover-ups: The Prosecutions of Margaret Porete and Guiard of Cressonessart, 1308-1310’, Speculum 89:4 (2014): 936-973. ${ }^{2}$ On the Mirror's reception in later medieval France, see Zan Kocher, 'The Apothecary's Mirror of Simple Souls: Circulation and Reception of Marguerite Porete's Book in Fifteenth-Century France', Modern Philology 111.1 (2013): 23-47; and Geneviève Hasenohr, 'La tradition du Miroir des simples âmes au XVe siècle: De Marguerite Porete (†1310) à Marguerite de Navarre', Comptes rendus des séances de l'Academie des inscriptions et belles-lettres 143:4 (1999), 1347-1366; and Hasenohr, 'La seconde vie du Miroir des Simples Ames en France: Le Livre de la Discipline d'Amour Divine (XVe-XVIII ${ }^{e}$ s.)', in Marguerite Porete et le Miroir, 263-317. On the Middle English reception, see Michael Sargent, 'Medieval and Modern Readership of
} 
side to the remarkable later medieval afterlife of the Mirror. While numerous readers across Europe were embracing the Mirror and its descriptions of perfect 'annihilation' in God, others continued to show suspicion and hostility towards its doctrines, and dedicated their time to opposing it both verbally and, in one case, physically. ${ }^{3}$ Fifteenth-century Italy in particular gave the Mirror a less-than-warm welcome. Here it was condemned in sermons, caught up in a Venetian inquisition, used to accuse a pope of heresy, and was confiscated from a number of people in Padua. ${ }^{4}$ These events were first noted by Romana Guarnieri in 1965, in her extensive publication 'Il movimento del libero spirito', which documented the history of what she believed to be the heretical 'sect' of the free spirit, a sect now widely acknowledged to have existed more in the minds of inquisitors than in actuality. ${ }^{5}$ Although these occurrences have been re-iterated by scholars after Guarnieri, there is one other instance of Italian opposition to the Mirror that has remained largely unnoticed for the past fifty years. In discussing the history of the Mirror in the context of the Council of Basel, where it was used to accuse Pope Eugenius IV of heresy, Guarnieri noted an intriguing entry in the

Marguerite Porete's Mirouer des Simples Âmes Anienties: The French and English Traditions', in Middle English Religious Writing in Practice: Texts, Readers, and Transformations, ed. Nicole Rice (Turnhout: Brepols, 2013), 47-89; Marleen Cré, Vernacular Mysticism in the Charterhouse: A Study of London, British Library, MS Additional 37790 (Turnhout: Brepols, 2006); Kathryn Kerby-Fulton, Books Under Suspicion: Censorship and Tolerance of Revelatory Writing in Late Medieval England (Indiana: University of Notre Dame Press, 2006), 272-296; Nicholas Watson, 'Melting into God the English Way: Deification in the Middle English Version of Marguerite Porete's Mirouer des simples âmes anienties', in Prophets Abroad: The Reception of Continental Holy Women in Late-Medieval England, ed. Rosalyn Voaden (Woodbridge, 1996), 19-49. On its reception in Italy see Romana Guarnieri, 'Il movimento del libero spirito', Archivio italiano per la storia della pietà 4 (1965): 466-476; Sargent, 'Medieval and Modern Readership of Marguerite Porete's Mirouer des simples âmes ames anienties: The Manuscripts of the Continental Latin and Italian Tradition', in The Medieval Translator/Traduire au Moyen Age 15: In principio fuit interpres, ed. Alessandra Petrine (Turnhout: Brepols, 2013), 85-96; and Justine Trombley, 'The Latin Manuscripts of The Mirror of Simple Souls', forthcoming in A Companion to Marguerite Porete and the Mirror of Simple Souls, ed. Robert Stauffer and Wendy Terry (Leiden: Brill).

${ }^{3}$ The fifteenth-century manuscript Oxford, Bodleian Library, MS Laud Latin 46 once contained a Latin Mirror, but this was excised from the codex, leaving only the first page, six stubs, and the final paragraph. This manuscript is briefly described in Paul Verdeyen's introduction to the 1986 page-facing Middle French and Latin edition of the Mirror. See Paul Verdeyen, introduction to Le Mirouer des Simples Ames/Speculum Simplicium Animarum, by Marguerite Porete, ed. Romana Guarnieri and Paul Verdeyen, in Corpus Christianorum Continuatio Mediaevalis (Turnhout: Brepols, 1986), XI-XII, [Hereafter Speculum CCCM], where he labels it manuscript 'E'. For a photograph of the full-page fragment see Kerby-Fulton, Books Under Suspicion, 277. This codex is also discussed in Sargent, 'Medieval and Modern Readership: The Continental Latin and Italian Tradition', 87-88, and Trombley, 'The Latin Manuscripts of The Mirror of Simple Souls'. Trends of opposition to the Mirror are particularly evident in its Latin manuscript tradition. This was the subject of my doctoral thesis, Justine Trombley, The Mirror Broken Anew: The Manuscript Evidence for Opposition to Marguerite Porete's Latin Mirror of Simple Souls in the Later Middle Ages (PhD diss., University of St Andrews, 2014), which includes a study of Laud Latin 46, the Vatican error list mentioned below, and a more in-depth study of the manuscript discussed here. I am now preparing this thesis for publication as a monograph. ${ }^{4}$ These events have been discussed in Guarnieri, 'Il movimento', 466-476; Sargent, 'Medieval and Modern Readership: The Manuscripts of the Continental Latin and Italian Tradition', 85-96; and Trombley, 'The Latin Manuscripts of The Mirror of Simple Souls'.

${ }^{5}$ See Robert E. Lerner, The Heresy of the Free Spirit in the Later Middle Ages, $3^{\text {rd }}$ ed. (Indiana: University of Notre Dame Press, 2007). 
fifteenth-century library catalogue of the Benedictine Congregation of Santa Giustina in Padua, which had been edited and printed by Luigi Alberto Ferrai in $1887 .{ }^{6}$ Amongst several manuscripts which had been bequeathed to Sta. Giustina by the Paduan professor of canon law Giacomo de Zocchi (d. 1457), there was one book containing a document bearing the title Plures detestationes seu reprobationes super multis contentis in quodam libro qui intitulatur Speculum simplicium animarum, or 'Several renunciations and rejections concerning many things contained in a certain book which is entitled The Mirror of Simple Souls. ${ }^{7}$ Guarnieri noted that this description sounded similar to a document found in a manuscript held in the Vatican Library, MS Vat. lat. 4953. This codex, also copied in the fifteenth century, contained a list of thirty extracts taken from a Latin Mirror copy which were then refuted with theological and scriptural citations. ${ }^{8}$ At the time of writing, Guarnieri stated that she had not yet discovered the present-day location of the Paduan manuscript, and she does not seem to have ever located it, as it makes no appearance in any of her later work on the Mirror. ${ }^{9}$ As recently as 2015 , this manuscript was listed on the International Marguerite Porete Bibliography under the heading of 'Lost Manuscripts?'10

Fortunately, it seems that 'forgotten' or 'overlooked' can now be its descriptor, for this manuscript does survive, and other Italian scholars did know of its modern holding. A 1956 publication by Luigi Montobbio mentioned it as one of four legal codices which had been left to the Congregation of Sta. Giustina by Giacomo de Zocchi, and he gave its modern callmark: Padua, Biblioteca universitaria, MS $1647 .{ }^{11}$ This information never seemed to

\footnotetext{
${ }^{6}$ Guarnieri, 'Il movimento', 473. The catalogue is Luigi Alberto Ferrai, La biblioteca di S. Giustina di Padova (Rome: Presso i Principali Librai, 1887). This is the second volume in a three-volume series done by Giuseppe Mazzatinti, Inventario dei manoscritti italiani delle biblioteche di Francia, 3 vols. (Rome: Presso i Principali Librai, 1886-1888).

${ }^{7}$ The Congregation of Sta Giustina had banned the Mirror from circulating within its houses in 1433. See Guarnieri, 'Il movimento', 468-469.

${ }^{8}$ Guarnieri transcribed and edited the Vatican document, and included her edition of it in the appendix to 'Il movimento' (649-660). Guarnieri believed the Vatican document to be the result of a theological assessment of the Mirror conducted in Padua in 1437, and that it was associated with an incident recorded in John of Segovia's record of the Council of Basel, in which a mysterious 'James', a master in arts and medicine, accused Pope Eugenius IV of favouring the Mirror of Simple Souls. This James declared that he had written up a list of errors taken from the work. See John of Segovia, Monumenta conciliorum generalium seculi decimi quinti: Concilium Basiliense, ed. F. Palacky and E. von Birk, vol. 3 part 3 (Vienna: Typus Adolphi Holzhausen, 1873), 341. On this incident see also Guarnieri, 'Il movimento', 474-475; Sargent, 'Medieval and Modern Readership: The Continental Latin and Italian Traditions', 88-89; and Trombley, 'The Latin Manuscripts of the Mirror of Simple Souls'. It is in this context that Guarnieri noted the Paduan manuscript, suggesting that the seeming similarity in content between the Vatican document and that mentioned in the Sta Giustina catalogue pointed to Giacomo de Zocchi as the real identity for James, and the document in his possession to be his list of errors against the Mirror. Guarnieri, 'Il movimento', 475.

9 Guarnieri, 'Il movimento', 473. 'Non ho ancora individuato il codice in questione.'

${ }^{10}$ Zan Kocher, International Marguerite Porete Bibliography, http://margueriteporete.net/\#lostmss.

${ }^{11}$ Luigi Montobbio, 'I quattro codici di Giacomo Zocchi', Benedictina 10 (1956): 55-56. A new edition of the library catalogue of Sta. Giustina done by Giovanna Cantoni Alzati in 1982, in which she linked the fifteenth-
} 
make the jump from those interested in Sta. Giustina to those interested in the Mirror. The purpose of this article is to finally make that jump, and re-introduce MS 1647 into the history of The Mirror of Simple Souls. It is an exciting find, not only because it is a 'new' addition to the corpus of available Mirror-related manuscripts, but also because its contents have the potential to change existing scholarly understanding of both the Mirror's Latin translation and several crucial aspects of the Mirror's broader history. ${ }^{12}$

\section{Padua, Biblioteca universitaria, MS 1647}

MS 1647 is a fifteenth-century paper codex of 224 folios which still has its original wood and leather binding. It was compiled no later than December of 1428, as there is a customs note in the bottom margin of its first folio which reads Dominus Jacobus de Ferraria (meaning de Zocchi, who came from Ferrara) conduxit die 22 decembris 1428 a.d. ${ }^{13}$ Watermark evidence points to an origin in Bologna between the years 1396-1428; this is supported by the fact that Giacomo de Zocchi received his degree in canon law there, and was then an academic there from 1425-1428, before moving permanently to Padua. ${ }^{14}$ After a commentary on the fourth

century entries with their modern callmarks, repeated Montobbio's designation. See Giovanna Cantoni Alzati, La Biblioteca di S. Giustina di Padova: Libri e cultura presso i benedettini padovani in età umanistica (Padua: Antenore, 1982), 102.

${ }^{12}$ As part of my doctoral work, I made a full transcription of this document and included it as an appendix to my thesis (Trombley, Mirror Broken Anew, 206-285). I am now preparing this transcription for publication as a critical edition. A full study of this document will also form a chapter in the monograph of my thesis.

${ }^{13}$ Montobbio gave the date as 'octobris', but this is a misreading. See 'Quattro codici', 55. Primo Griguolo gives the correct month in 'Per la biografica del canonista Ferrarese Giacomo Zocchi(† 1457): 1'insegnamento, la famiglia, i libri', Quaderni per la storia dell'Università di Padova 44 (2011): 185. The note was an official 'stamp of approval', showing that the book was allowed to be imported into Padua tax-free. On these customs notes see Luciano Gargan, 'L'enigmatico “conduxit”: libri e dogana a Padova fra Tre e Quattrocento', Quaderni per la storia dell'università di Padova, 16 (1983), 1-41; Gargan, 'Nuovi codici “condotti” a Padova nel Tre e Quattrocento', Quaderni per la storia dell'università di Padova, 22-23 (1989-90), 1-57; and Gargan, 'Le note “conduxit”. Libri di maestri e studenti nelle Università italiane del Tre e Quattrocento', in Manuels, programmes de cours et techniques d'enseignement dans les Universités médiévales, ed. Jacqueline Hamesse, (Louvain-la-Neuve: Université catholique de Louvain, 1994), 385-400. MS 1647 is the third volume in a set of four, each one containing a volume of Antonio de Butrio's commentary on the Decretals. These other codices are also held by the Biblioteca universitaria, as MSs 1645, 1646, and 1648. For a brief description of all four see Montobbio, 'Quattro codici'. All but one (MS 1648) contain the same customs note as MS 1647. ${ }^{14}$ Annalisa Belloni, Professori giuristi a Padova nel secolo XV: Profili bio-bibliografici e cattedre (Frankfurtam-Main: Vittorio Klostermann, 1986), 216, and Griguolo, 'Per la biografica', 184 and 185. There are three watermarks in total: a rampant lion, a dragon, and a three-mountain design, the two most frequently occurring marks being the lion and the dragon. The lion appears on 69 folios, and closely resembles \#10500 in Briquet, from Bologna between 1420-1430. See Charles Moise Briquet, Les filigranes dictionnaire historique des marques du papier dès leur apparition vers 1282 jusqu'en 1600 vol. 3 (Paris, 1907), 540. Accessed online at Briquet Online, by the Österreichische Akademie der Wissenschaften and the Laboratoire de Médiévistique Occidentale de Paris,

http://www.ksbm.oeaw.ac.at/_scripts/php/loadRepWmark.php?rep=briquet\&refnr=10500\&lang=f. The dragon is a close match to Piccard \#461, from Bologna in 1411, appearing on 28 of the folios. See G. Piccard, Die Wasserzeichenkartei Piccard im Hauptstaatsarchiv Stuttgart: Findbuch, vol. 10, Fabeltiere: Greif, Drache, 
book of the Decretals by the fourteenth-century canonist Antonio de Butrio (1338-1408, ff. 1r-124r), decisions from the Roman Rota up to 1381 by William of Horborch (ff. 134r-202v), and a copy of the Impugnacio cathedre sedis Romane ecclesie in concilio Constanciensi eiusdemque defensio of 1417 (ff. 209r-215r), seven folios (215v-221v) of the last quire in the manuscript contain the document which Guarnieri noted: a work which attacks and refutes thirty-five extracts from a Latin copy of The Mirror of Simple Souls. ${ }^{15}$ Despite comprising only seven folios, it is nevertheless a substantial piece of work: Copied in de Zocchi's own hand on pages measuring approximately $44.7 \times 30.7 \mathrm{~cm}(17.6 \times 12.0 \mathrm{in})$, the text is laid out in two columns of over a hundred lines each, in tiny handwriting. This amounts to approximately eighty pages of transcribed text. Crucial to this article's main argument is the fact that, though written out by de Zocchi, the evidence makes it clear that it was not originally authored by him. There are several areas where a few words or an entire sentence are crossed out, which are then re-written a few lines later. The same occurs within lines themselves, where a wrong word is crossed out and then re-written a few words further on. These are not later interpolations — though there are a few of those as well—but corrections made internally in the text in the process of writing, indicating that de Zocchi was referring back to an exemplar, rather than composing on the spot. ${ }^{16}$ The document's physical appearance contrasts noticeably with that of the other texts in MS 1647. The Decretals commentary, the Roman Rota decisions, and the Impugnacio begin on rectos, have neat, even columns, coloured initials beginning each section (with the exception of the Impugnacio, which has unexecuted initials), and each are copied in different hands. In contrast, the antiMirror treatise starts on a verso, with varying column widths, lines of text which do not run straight, has unexecuted initials throughout, and was copied by de Zocchi himself in a style of

\footnotetext{
Einhorn (Stuttgart: Kohlhammer, 1980), \#461. The three-mountain design only appears on 6 folios, and most closely matches Piccard \#456 and \#459, both from Bologna in 1417 and 1414, respectively. See Piccard, Die Wasserzeichenkartei Piccard im Hauptstaatsarchiv Stuttgart: Findbuch, vol. 16, Dreiberg 2 (Stuttgart: Kohlhammer, 1996). The watermarked pages are not grouped together in specific sections, but are rather mixed randomly throughout the manuscript. Thus they cannot be used to discern any distinct stages of assembly. ${ }^{15} \mathrm{ff} .124 \mathrm{v}-126 \mathrm{v}$ are blank; $127 \mathrm{r}-131 \mathrm{v}$ contain a table of contents for the Roman Rota decisions, organised numerically. 132r-133v are blank; 203r-208r contain another table of contents for the Rota decisions, this time organised by subject, which is also written out in de Zocchi's hand. 208v is blank, and the final three folios, $222 \mathrm{r}-224 \mathrm{v}$, are also blank. There seem to be no modern editions of either de Butrio's Decretals commentary nor William of Horborch's Roman Rota decisions, but Heinrich Finke published an edition of the Impugnacio in his Forschungen und Quellen zur Geschichte des Konstanzer Konzils (Paderborn: Ferdinand Schöningh, 1889), 288-297. The Impugnacio has not previously been identified in this codex. Montobbio mentioned it in passing before noting the folios of the anti-Mirror treatise, but referred to it only as some 'legal references' (richiami di carattere giuridico). See Montobbio, 'Quattro codici', 56.

${ }^{16}$ For example on f. $220 \mathrm{v}$, where the beginning of a sentence in line 8 of column 2 ('procul dubio ergo') is crossed out in line 6, where it was mistakenly written in the middle of a quotation from Psalms 100:1.
} 
handwriting he usually reserved for writing marginal comments. ${ }^{17}$ This gives the impression that the anti-Mirror document was perhaps included in the manuscript as an afterthought. It is possible that de Zocchi had acquired and owned the other works first in unbound, fascicle form, and then came across the exemplar of the Mirror document later, before having the codex bound. Since the Impugnacio ends at the beginning of a quire, there would have remained several blank leaves after it. ${ }^{18}$ Taking advantage of this extra space, he then copied out the Mirror document himself before having the entire collection bound.

The document takes the form of quotation followed by refutation-a direct quotation from a Latin Mirror is written out as a separate block of text, and then followed by a refutation which uses canon-legal, scriptural, and theological authorities to show how the excerpted passage is 'erroneous'. In this way, Guarnieri's observation that it is similar in nature to the document found in Vat. lat. 4953 is correct. The similarity, however, ends there. The Vatican document is very much a list, where excerpts are laid out and refuted in a systematic, pointby-point style which contains little or no personal opinion or rhetoric. By contrast, the document in MS 1647 is much more of a treatise, with a narrative flow and an opinionated authorial voice which imbues the text with colourful, invective language. What's more, the Paduan document is complete, whereas the Vatican one begins suddenly with a Mirror quotation and no incipit, and ends abruptly in the middle of another Mirror extract. ${ }^{19}$

The author of the Paduan document was undoubtedly working from a Latin version of the Mirror, and not merely translating extracts himself from a vernacular copy, as the quotations he uses match up nearly verbatim with the same passages found in Verdeyen's modern edition of the Latin. At certain points the author seems to be paraphrasing a passage, making textual comparison difficult in some areas, but in general, the extracts in MS 1647 more often match the Vatican Mirror codices Rossianus 4 (Verdeyen's manuscript 'B'), Chigianus B IV

\footnotetext{
${ }^{17}$ De Zocchi seems to have had two handwriting styles, one with larger letter forms and a neater, more careful ductus, used for copying out main texts - such as that which he used to write out the second table of contents for the Roman Rota decisions on ff. 203r-208r-and a smaller, more rapid and less legible hand which he normally uses to comment on particular works, such as his marginal comments on the Decretals commentary on ff. 86v87r. He employs both of these styles in the Mirror document, using the neater hand to copy out the Mirror quotations, and his commenting hand to write the refutations.

${ }^{18}$ The last quire (ff. 215-224) comprises the last page of the Impugnacio (f. 215r) and the entire anti-Mirror treatise $(215 \mathrm{v}-221 \mathrm{v}) .222 \mathrm{r}-224 \mathrm{v}$ are blank.

${ }^{19}$ See Guarnieri, 'Il movimento', 660. Additionally, the latest date for the manuscript's genesis, 1428, places it nine years earlier than the incident at the Council of Basel, and the career of Giacomo de Zocchi seems to discount him as a potential candidate for the mysterious accuser James, as the recent biography done by Primo Griguolo does not indicate any links with the Council of Basel, and he seems to have been closely connected to movements and institutions which were led by close friends and supporters of Eugenius IV; it seems unlikely that he would have brought charges of heresy against him. See Griguolo, 'Per la biografica del canonista', at 198 and 203.
} 
41 ('C'), and Chigianus C IV 85 ('D') in their readings than with Vat. lat. 4355 ('A'). ${ }^{20}$

Furthermore, the author appears to have had an entire copy of the Mirror in front of him, and not merely a compilation of excerpts, as not only does he reference chapter and page numbers in the extracts, but he occasionally uses additional passages from the Mirror itself in his refutations, as supplements to some of his arguments. ${ }^{21}$ A full copy is also indicated in the beginning of the document, where the author notes that errors can be found 'from the beginning of this little work all the way up to the end' (a principio huius opusculi usque in finem). ${ }^{22}$ Thus this document provides a glimpse — however hazy — of another once-extant complete Latin Mirror copy. ${ }^{23}$

Like many later readers of the Mirror, the author of this document was completely unaware of the Mirror's origins and its clashes with authority, though, as we shall see, he would not have been unhappy to hear of its Valenciennes and Parisian condemnations. His unawareness is revealed in the very first sentence of the document, where he uses the term apocryphus to describe the Mirror, and he repeatedly refers to the author of the Mirror as male, calling 'him' a hereticus and not a heretica. ${ }^{24}$ Before addressing individual Mirror passages, the author provides an introduction, in which he assesses the work as a whole, and makes his opinion of it abundantly clear. The Mirror, in addition to being apocryphal—and therefore devoid of canonical authority — was also clearly invented entirely out of its author's own head, without any support from scripture or the doctors of the Church. ${ }^{25}$ This is the main theme of the introductory passage, and it is reinforced with biblical quotations and citations from Gratian's Decretum. Thus, by the time the author turns to attacking specific errors of the Mirror, he has firmly established that the work as a whole is unacceptable and heretical.

\footnotetext{
${ }^{20}$ See Verdeyen, Introduction to Speculum CCCM, VIII-XII. Comparison with codex 'E' (Laud Latin 46) is not possible, as no passages from MS 1647 are taken from the sections which survive in E's fragments.

${ }^{21}$ For example on f. 221r, where, after writing out the thirty-fifth error (Speculum CCCM, 313) he copies the passage which precedes it (Speculum CCCM 311-313, beginning 'ego sum summam...'). The author also mentions column numbers at various points, which, unusually, go up as high as four.

22 Padua, Biblioteca universitaria, MS 1647, f. $215 \mathrm{v}$.

${ }^{23}$ Worthy of note is the fact that the author does not cite any excerpts past Chapter 117 (in the Chantilly MS reckoning of chapters, which are those used by Verdeyen in the standard edition), and does not make any mention of the appraisals from John of Quérénaing, Franco of Villers, and Godfrey of Fontaines, which consistently appear at the end of the Latin version (see Speculum CCCM 405-409). This perhaps indicates that the version the author of this document had was missing the Mirror's final chapters, a characteristic which merits further investigation.

${ }^{24}$ For example in the concluding paragraph on $\mathrm{f} .221 \mathrm{v}$, he writes 'hunc hereticum consuo opere relinquimus.' (My emphasis.) This use of the masculine case does not cast doubt on the fact that the Mirror was originally written by a woman. Rather, along with the use of the term apocryphus, it merely shows the extent to which the author was unaware of the Mirror's origins and authorship, and thus assumed male authorship as the default. ${ }^{25}$ MS Padua 1647, f. 217v. 'Quicquid asserit totum ipsius auctor ex proprio capite traxit sine ulla allegationem scripturis aut sanctorum doctorum'.
} 
Overall, four major areas of concern regarding the Mirror's doctrines can be distilled from the thirty-five extracts which appear. These are:

(1) The Soul's indifference to any kind of feelings attached to moral guidanceparticularly the Virtues (faith, hope, charity), but also shame, honour, fear, hate, love, and the Soul's proclaimed ability to do whatever it pleases.

(2) The Soul's rejection of normal Christian practices, i.e. sermons, prayer, fasting, the sacraments, as well as the Mirror's belittling of the institutional church by naming it Ecclesia Minor.

(3) The Soul's self-acquisition of divine knowledge without guidance from or dependence on church teachings, and with no justification given for how this knowledge was acquired.

(4) The equation of the Soul with God; the assertion that the annihilated Soul has essentially achieved a status of divinity on a par with God himself.

On the whole, it is not surprising that these are the areas which most disturbed the author. The first two areas essentially match up in subject with the two errors cited in the theologians' assessment of the Mirror found in Marguerite's trial documents, and another found in a chronicle account of her execution, which were:

(1) That the annihilated soul gives license to the virtues and is no longer in servitude to them, because it does not have use for them, but rather the virtues obey its command.

(15) That such a soul does not care about the consolations of God or his gifts, and ought not to care and cannot, because such a soul has been completely focused on God, and thus its focus on God would be impeded. ${ }^{26}$

That the Soul annihilated in love of the Creator, without blame of conscience or remorse, can and ought to concede to nature whatever it seeks and desires. ${ }^{27}$

\footnotetext{
${ }^{26}$ From the theologians' judgment of the Mirror, recorded in Paris, Archives National, J 428 no. 15. Printed editions of the Latin are found in Paul Verdeyen, 'Le procès d'inquisition contre Marguerite Porete et Guiard de Cressonessart', Revue d'histoire ecclesiastique 81 (1986): 51. The English here is taken from Field, BAI, 128. ${ }^{27}$ From the continuation of the chronicle of Guillaume de Nangis. Paul Verdeyen, 'Le process', at 51 and 88. English taken from Field, BAI, 128 and 234.
} 
These concerns are also expressed in the decree Ad nostrum, the document first generated at the Council of Vienne in 1311 which famously defined and condemned eight errors attributed to beguines and beghards and which was used throughout the fourteenth and early fifteenth centuries as an interrogatory used to identify the 'heresy of the free spirit'. ${ }^{28}$ It was also used to attack the Mirror itself in the fifteenth century, which is discussed further below. Six of the eight errors in Ad nostrum closely resemble the concerns expressed above:

(1) That a person in this present life can acquire a degree of perfection, which renders him utterly impeccable and unable to make further progress in grade.

(2) That it is not necessary to fast or pray after gaining this degree of perfection, for then the sensitive appetite has been so perfectly subjected to the spirit and to reason that one may freely grant the body whatever pleases it.

(3) That those who have reached the said degree of perfection and spirit of liberty are not subject to human obedience, nor obliged to any commandments of the church.

(4) That a person can gain in this life final beatitude in every degree of perfection that he will obtain in the life of the blessed.

(5) That any intellectual nature in itself is naturally blessed, and that the soul does not need the light of glory to elevate it to see God and enjoy him blissfully.

(6) That the practice of the virtues belongs to the state of imperfection and the perfect soul is free from virtues. ${ }^{29}$

\footnotetext{
${ }^{28}$ On inquisitorial usage of Ad nostrum see in general Lerner, Heresy of the Free Spirit; Richard Kieckhefer, The Repression of Heresy in Medieval Germany (Liverpool: Liverpool University Press, 1979), 21-32; and Lerner, 'Meister Eckhart's Specter: Fourteenth-Century Uses of the Bull In agro dominico Including a Newly Discovered Inquisitorial Text of 1337', Mediaeval Studies 70 (2008): 115-134.

${ }^{29}$ Clem. 5.3.3. For the Latin text of Ad nostrum, see Emil Friedberg, ed., Corpus iuris canonici, vol. 2, (Leipzig: Tauchnitz, 1881), cols. 1183-84, and also Elizabeth Makowski, 'When is a Beguine not a Beguine? Names, Norms, and Nuance in Canonical Literature', in Labels and Libels: Naming Beguines in Northern Medieval Europe, ed. Letha Böhringer, Jennifer Kolpacoff Deane, and Hildo van Engen (Turnhout: Brepols, 2014), 9394. The English translations here are also taken from Makowski, 'When is A Beguine not a Beguine?', 94-95. On the relationship between Ad nostrum and the anti-beguine decree Cum de quibusdam see Jacqueline Tarrant, 'The Clementine Decrees on the Beguines: Conciliar and Papal Versions', Archivum historiae pontificae 12 (1974): 300-308; also Elizabeth Makowski, A Pernicious Sort of Woman: Quasi-Religious Women and Canon Lawyers in the Later Middle Ages (Washington D.C.: Catholic University of America Press, 2005), 23-50. On the relationship of these two decrees to the perception and treatment of beguines, see Labels and Libels, especially the essays in that volume by Jennifer Kolpacoff Deane, Makowski, and Sean L. Field. The seventh and eighth errors of Ad nostrum, which bear less resemblance to anything contained in the Mirror, are: 'That to kiss a woman is a mortal sin since nature does not incline one to it, but the act of intercourse is not a sin, especially in time of temptation, since it is an inclination of nature', and 'That at the elevation of the body of Jesus Christ, they ought not to rise or show reverence to it; it would be an imperfection for them to come down
} 
Thus the issues to which the author of the anti-Mirror document objected are the areas which one would expect to be objected to.

What is new, however, is the author's explanation of why these Mirror extracts should be considered erroneous. His refutations are detailed and lengthy, with a wealth of scriptural and canon-legal citations to reinforce his assertions. This level of detail is something which has previously been unavailable to Mirror scholars. If the twenty-one theologians who assessed the Mirror in 1310 ever gave an explanation of their decision, William of Paris declined to include it in the documents pertaining to Marguerite's trial. While the document in Vat. lat. 4953 does provide further reasoning against the Mirror, it cannot match MS 1647 in its detail and its completeness, and it is vastly less passionate in its denouncement of the Mirror. Indeed, what is truly unique about the document in MS 1647 is its rhetoric and style. The author's attacks on the Mirror are filled with a vehemence and sense of outrage which stands in sharp contrast to the dry, academic tone of the Vatican document. In many ways, the work is similar in nature to the anti-heretical writings of the thirteenth century, employing much of the same style, imagery, and arguments of which that tradition frequently made use. ${ }^{30}$

What charges, then, does this anonymous author lay at the Mirror's door? Two chief allegations recur regularly: sinfulness and arrogance. The first is primarily framed in light of the Soul's famous departure from the Virtues, and its belittling of church practices. ${ }^{31}$ Abandoning the Virtues encourages man to sink into vice, since, as the author writes, 'the departure of the virtues works the entry of evil'. ${ }^{32}$ This, along with the rejection of Church practices, is presented as rejecting one's own salvation, since salvation cannot be achieved without either of these. The charge of arrogance is levelled against the Mirror's claim to divine knowledge, as the author states that none of its assertions have any proof to reinforce them, and to claim such knowledge without any proof is 'foolish and worthless' (fatua et vacua $).{ }^{33}$ Arrogance is also the chief accusation against the Mirror's famous assertion that the

from the purity and height of their contemplation so far as to think about the ministry or sacrament of the Eucharist, or about the passion of Christ as man.' English from Makowski, 'When is a Beguine not a Beguine?', 95.

${ }^{30}$ For a survey of this literature see L.J. Sackville, Heresy and Heretics in the Thirteenth Century: The Textual Representations (York: York Medieval Press, 2011).

${ }^{31}$ For examples see Speculum CCCM, 25 (for departure from the Virtues) and 75 (for belittling the institutional Church).

${ }^{32}$ MS 1647, f. 216r. 'egressus enim uirtutum malitie operatur ingressum'. This is actually the author's inversion of a quotation from the Decretum, C. 32 q. 1 c. 9 (to which the author directs the reader). See Friedberg, Corpus iuris canonici, vol. 1, col. 1117.

${ }^{33}$ MS 1647, f. 219r. 
Annihilated Soul has become God himself. ${ }^{34}$ This, in the eyes of the author, is the height of wickedness and the sin of pride. He directly equates the Annihilated Soul with Satan in this regard, at one point comparing it with both the serpent tempting Eve (Genesis 3:5) and with Lucifer's attempt to rival the power of God (Isaiah 14:14). ${ }^{35}$

These are vivid comparisons, and, indeed, the further one reads in this document, the more apparent it becomes that the author does not merely view the Mirror as an erroneous book, but an evil one, a book which, like Satan himself, is tempting others to commit mortal sin with promises of achieving a God-like state through rejecting traditional church teachings and virtuous behaviour. His rhetoric makes this abundantly clear. The Mirror's assertions are described as 'poisonous' (venenosa), 'false, deceitful, and heretical' (falsa, ficta, et heretica), and as coming from 'tartarean [i.e. demonic] council' (ex concilio tarthareo). To him the Mirror speaks with a vox diabolica, a 'diabolical voice', and it 'vomits out' (evomit) venom, lies, and deceit. At one point he invokes the image of a snake lurking in its words (hic latet anguis in verba). Marguerite's famous 'Holy Church the Greater', the church of the Simple Souls, is designated as the 'synagogue of Satan' (sinagoga satane) from Apocalypse 3:9, and is called a 'chimera' (chimera) and a 'monster' (monstrum). As noted above, the Simple Soul itself is equated with Satan, and is an 'evil spirit' (malignus spiritus) which 'is lying prostrate in the filth of the vices, and is fixed deep in the muck, and is stripped of the Virtues without any inward cure or other works of goodness. ${ }^{36}$ Along with being evil, the Mirror is also portrayed as ignorant. Its arguments are variously described as 'stupid' (stolidus), 'folly' (fatuitas), and, as noted above, 'foolish and worthless'. At one point he even invokes the image of a bumpkin or a boor, writing 'We see how he speaks churlishly (rusticaliter) about Christ'. 37

\footnotetext{
${ }^{34}$ Marguerite states this at least three times. See Speculum CCCM, 81-83, 151, and 313.

${ }^{35}$ MS 1647, f. 219v. 'Vox ista vox diabolica est, similis illi qua suggessit Eve contravenire mandato domino Dei: "Eritis sicut dii, scientes bonum et malum" [Genesis 3:5] et illi que presumpsit velle se equiperare creatori suo cum dixit "Ascendam super altitudinem [MS 'altitudienem'] nubum et ero similis altissimo", Ysaie xiiii [Isaiah 14:14].'

${ }^{36}$ Ibid., f. 219 r. 'iacentem in ceno uitiorum et infixam in limo profundi, et nudatam omnibus uirtutibus sine ullo remedio penitudinis, sine aliquibus operibus bonis'.

${ }^{37}$ Ibid., f. 220r. 'videmus quomodo rusticaliter loquitur de christo'. This image of the unrefined 'rustic' is an interesting contrast to Marguerite's emphasis on and her frequent use of courtly language and metaphors of elite social status. On this courtly discourse see Barbara Newman, 'La mystique courtoise: Thirteenth-Century Beguines and the Art of Love', in From Virile Woman to WomanChrist: Studies in Medieval Religion and Literature (Philadelphia: University of Pennsylvania Press, 1995), 137-167; Newman, 'The Mirror and the Rose: Marguerite Porete's Encounter with the Dieu d'Amours', in The Vernacular Spirit: Essays on Medieval Religious Literature, ed. Renate Blumenfeld-Kosinski, Duncan Robertson, and Nancy Bradley Warren (New York: Palgrave, 2002), 105-123; Newman, Medieval Crossover: Reading the Secular Against the Sacred (Indiana: University of Notre Dame Press, 2013), 111-165; see also Suzanne Kocher, Allegories of Love in Marguerite Porete's Mirror of Simple Souls (Turnhout: Brepols, 2008); Joanne Maguire Robinson, Nobility and
} 
The author is unrelenting in his criticism, and takes a very literal approach to the Mirror. He clearly has no patience for the paradoxes and metaphors of speculative mysticism, as these are taken at face value. This occasionally produces an almost comic result, such as his response to one of Marguerite's expressions of humility. Where Marguerite writes that she knows herself to be 'the root of all evil and the abundance of sin', the refuter responds 'I believe this consideration to be true'. ${ }^{38}$ Unlike another commenter on the Mirror, the Middle English translator M.N., he displays no willingness to accommodate any of the Mirror's assertions, and his characterisation of it as 'diabolical' demonstrates clearly that this is a work which is not only unacceptable, but dangerous. ${ }^{39}$ This is driven home in the conclusion of the work, where the author says precisely what he thinks ought to be done with the Mirror. He writes: 'We pursue this heretic with his work, and we abandon (relinquimus) this heretic with his work to be burned by fire' ${ }^{40}$ This is a striking, even eerie pronouncement, not only because it clearly indicates that the author was writing with no knowledge of the Mirror's other conflicts with authority, but also for the fact that, despite this lack of knowledge, he came to precisely the same conclusion as those who prosecuted Marguerite in 1310.

Who was this man who so fervently believed the Mirror to be worthy of destruction? At this juncture, there is very little evidence to go on, and only a vague sketch can be compiled. It was most certainly the work of a single man. Though he frequently makes use of 'we' in his refutations, occasionally he slips into the first person singular, showing the 'we' to be merely a stylistic choice. His use of the first person combined with the emotional tone of the work indicate that he was probably acting against the Mirror on his own initiative, rather than on a commission from someone else. Though his judgment that the Mirror ought to be burned carries echoes of inquisitorial language, such as in his use of the word relinquimus, it does not quite carry the formality that one would expect from an official condemnation. So his statement that the heretic 'ought to be burned' suggests that, though he may have been familiar with inquisitorial language and forms, he may not have been an inquisitor himself, as standard inquisitorial sentencing usually involved the phrase 'relaxation to the secular arm' rather than 'burning. ${ }^{41}$ That he was well versed in canon law is certain; whether or not he

\footnotetext{
Annihilation in Marguerite Porete's Mirror of Simple Souls (Albany, New York: SUNY Press, 2001); and Jean René Valette, 'Marguerite Porete et le discours courtois', in Marguerite Porete et le Miroir, 169-196.

${ }^{38}$ Ibid., f. $217 \mathrm{v}$. 'Ego credo hanc consciderationem esse veram'.

${ }^{39}$ For the glosses of M.N. in the Middle English Mirror see Marguerite Porete, The Mirror of Simple Souls: A Middle English Translation, ed. Marilyn Doiron, in Archivio Italiano per la storia della pietà V (1968).

${ }^{40}$ Ibid., f. 221v. 'hunc hereticum cum suo opere prosequimur [MS 'presequimur'] et hunc hereticum cum suo opere relinquimus igne cremandum'.

${ }^{41}$ I thank Sean Field for pointing this out. Personal correspondence.
} 
was actually a canon lawyer is less so, but his detailed knowledge of Gratian's Decretum and the Decretals, and his use of legal vocabulary make it likely. His literal, un-nuanced interpretation of the Mirror indicates that he did not at all care for speculative mysticism, and he certainly had no patience for the paradoxical, metaphorical language of such mysticism. He assesses the Mirror almost entirely upon a legal and scriptural basis, with only a few theological citations. He is meticulous — one could even say pedantic — in his approach, often revisiting and re-refuting the same point multiple times.

His citations are also revealing. This was a highly literate and well equipped man. He was certainly familiar with anti-heretical legislation, as he makes multiple references to the decrees Ad abolendam of 1184 and Cum ex iniuncto of 1199, as well as referencing the relevant sections in the Decretum which deal with heresy. ${ }^{42}$ Most of the time he does not merely cite a source, but provides whole blocks of verbatim text from that source, indicating that he surely had access to physical copies of most of the works from which he quoted. This amounts to an impressive array of books at his disposal, either personally owned or to which he had access in some way. He certainly used a Bible and a copy of Gratian. He probably owned a copy of the Decretals and the Liber Sextus. His use of long quotations from two of Bernard of Clairvaux's Sermons on the Song of Songs suggests that he owned a copy of at least two of these sermons. ${ }^{43}$ Other works include a few gospel commentaries by St Ambrose, several works by Augustine, two works by Leo I, the Magna Moralia and a few homilies of Gregory the Great, the Sentences of Peter Lombard, a copy of Hrabanus Maurus's Commentary on Wisdom, and he may have been familiar with, if not in possession of, Thomas Aquinas's Summa Theologica and Catena Aurea. Whoever the author was, he had a wealth of texts at his disposal in his fight against the Mirror.

This level of textual access and the legal expertise of the author brings me to what is potentially the most important and exciting aspect of this document, not only for examination

\footnotetext{
${ }^{42}$ For example in his introductory passage, where he assesses the entire work, he refers the reader to Gratian's Causa 24, q. 3, c. 26, 27, and 28, which offer definitions of what a heretic is. For an overview of Gratian's treatment of heresy see Sackville, Heresy and Heretics, 100-107. An example of his use of anti-heretical decrees from the Liber Extra can be found on ff. 219r-v, in responding to a passage from the Mirror which states that the Soul has heard form the Holy Spirit that God will put the least in the highest place, and thus the Soul has no anxiety over any sin which she may commit [see Speculum CCCM, 127-129]. The author refutes this by referring to Cum ex iniuncto - a decree which, among other things, dealt with unsubstantiated claims to divine knowledge - because the Soul's claim to having knowledge from the Holy Spirit cannot be proven by any legitimate authority (f. 219r). The author then also references Ad abolendam in this section, referring to the lack of anxiety over sin, saying that this implies that man can be saved without penitence (posse salvari sine penitentia), which is 'false and heretical, in the chapter ad abolendam de hereticis' (falsum et hereticum, in capitulo ad abolendam [MS 'habolendam'], de hereticis) (f. 219v). See below for further discussion of the use of anti-heretical decrees in this document.

${ }^{43}$ MS 1647, ff. 216r and 218v, where Sermon 1 and Sermon 86 are quoted, respectively, on the subject of withdrawing from evil, and on the value of the virtues.
} 
of the treatise itself, but also for the history of The Mirror of Simple Souls in general. In transcribing this document, I noticed that amongst all the distinctions, causas, and capitulos of the Decretum and the Decretals which are used against the Mirror, there is one legal text - and collection of texts - which are conspicuously absent. At no point in this document is $\mathrm{Ad}$ nostrum, the anti-heretical decree noted above, cited. Indeed, no Clementine decree at all is mentioned anywhere in the text. The last major compilation of canon law to be published in the Middle Ages, the Clementines were well known and heavily commented upon, and would have been a standard text for any canonist to have. As noted above, Ad nostrum was a mainstay of anti-heretical legislation in the fourteenth and fifteenth centuries and frequently used as an inquisitorial interrogatory, and its close resemblance to the Mirror's doctrines has received much scholarly comment. ${ }^{44}$

Nor was this resemblance between the two lost on other medieval readers and critics of the Mirror. The hugely popular fifteenth-century Franciscan preacher Bernardino of Siena attacked the Mirror a number of times in his sermons; in at least two of these, he explicitly links the Mirror with Ad nostrum, at one point even suggesting that the errors of Ad nostrum had their origin in the Mirror. ${ }^{45}$ This belief is also expressed in an anonymous fifteenthcentury treatise against beghards, owned by Johannes Wenck, a theologian at the University of Heidelberg. In attacking the 'errors of the beghards', the treatise notes that six errors (those of Ad nostrum) 'burst forth and spread' (pullularent) from a book entitled De simplici anima, a copy of which was owned by the Carthusians of Strassburg. ${ }^{46}$ James Grenehalgh, the early sixteenth-century annotator of Richard Methley's Latin translation of the Mirror - which he made from its Middle English version - found in Cambridge, MS Pembroke College 221, directed readers to Ad nostrum with a note written on the work's title page. ${ }^{47}$ Finally, the

\footnotetext{
${ }^{44}$ See for example Lerner, The Heresy of the Free Spirit, 81-83; Kent Emery Jr., Foreword to The Mirror of Simple Souls, trans. and ed. Edmund Colledge, J.C. Marler, and Judith Grant (Indiana, 1999), ix and xi; and Field, BAI, 197-199.

${ }^{45}$ See Bernardino of Siena, 'Feria secunda post dominicam in quinquagesima: Articulus III, caput 1', in Sancti Bernardini Senensis Ordinis Seraphicis Minorum: Opera Omnia vol. 1, ed. Jean de la Haye (Lyon, 1650), 16. Accessed online: http://books.google.co.uk/books?id=Ve9zqawb8fUC\&pg=RA1-PA16\&lpg=RA1PA16\&dq $=\% 22$ condemnatur+doctrina + libri $\% 22 \&$ source $=b l \& o t s=2 C a G t n t k D f \& s i g=n d b E K 91 B 3 Q d B E P L S 70 a$

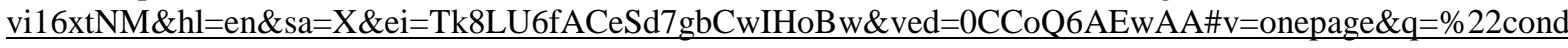
emnatur\%20doctrina\%20libri\%22\&f=false. This is cited in Guarnieri, 'Il movimento', 467. See also Bernardino of Siena, Opera Omnia vol. 3, ed. Pacifico Perantoni and Augustino Sepinski (Florence: Ad Claras Aquas, 1952), 109. On Bernardino's treatment of the Mirror see Guarnieri, 'Il movimento', 467-368, and Trombley, 'The Latin Manuscripts of the Mirror of Simple Souls'.

${ }^{46}$ Vatican, Biblioteca apostolica vaticana, MS Pal. lat. 600, f. 229v, noted in Rudolf Haubst, Studien zu Nikolaus von Kues und Johannes Wenck aus Handschriften der Vatikanischen Bibliothek (Münster: Aschendorff, 1955), 119. Also noted by Lerner (citing Haubst), Heresy of the Free Spirit, 170.

${ }^{47}$ See Richard Methley, Speculum animarum simplicium: A glossed Latin version of 'The Mirror of Simple Souls', ed. John Clark, Analecta Cartusiana 266 (Salzburg, 2010), 1. Also noted in Kerby-Fulton, Books Under Suspicion, 276.
} 
discrepancy between the Vatican error list and MS 1647 further highlights its absence from the latter. As mentioned earlier, the Vatican list's references are much more theologically based, in contrast to the legal mindset of MS 1647's author. References to authorities such as Augustine, Peter Lombard, or Bonaventure far outnumber any references to legal texts such as the Decretum or the Decretals. Yet, despite the lack of other legal citations, Ad nostrum still makes numerous appearances in the Vatican document - it is by far the most cited legal text, used against six Mirror quotations; five of these same quotations also appear in MS 1647. Thus there is clear evidence that Ad nostrum was frequently linked to the Mirror, and was the 'go-to' legal text for those looking to criticise it. What's more, in the cases of Bernardino and the anonymous treatise, the errors of Ad nostrum were even thought to have originated with the Mirror.

This makes the absence of Ad nostrum from the document in MS 1647 highly interesting. It seems unlikely that this is due merely to ignorance or oversight. The author clearly has professional and detailed knowledge of canon law, and gives every impression of trying to be as thorough and meticulous as possible, making numerous citations to drive home even a single point. As noted above, he draws upon every major collection of law from the Decretum up through the Liber Sextus of 1298, but makes no mention of the Clementines. He also knows other mainstays of anti-heretical legislation, Ad abolendam and Cum ex iniuncto, and the relevant sections in the Decretum. If he could see the relevance of these decrees to his arguments, then surely any canonist worth his salt would not fail to use $\mathrm{Ad}$ nostrum, the most relevant, recent, and useful decree at his disposal. But he does not. ${ }^{48}$

\footnotetext{
${ }^{48}$ Comparison with Vat. lat. 4953 most noticeably highlights this absence. To give just a few examples: Both Vat. lat. 4953 (on f. 29v, see Guarnieri, 'Il movimento', 653, for the printed version) and MS 1647 (on f. 217r) have as their seventh error the passage wherein Marguerite states that the annihilated Soul neither desires nor despises poverty, masses, sermons, prayers, etc. and gives to nature all that is asks without remorse of conscience (see Speculum CCCM, 33). Vat. lat. 4953 immediately refutes this with Ad nostrum (and the second error of Ad nostrum is almost an exact match in content to the Mirror extract in question; see above). The only specific anti-heretical legislation which MS 1647 references, however, is Ad abolendam (as well as a number of references to Gratian and one other non-heretical decree from the Liber Extra, De sponsalibus et matrimonio [X 4.1.6]). Both manuscripts also quote a passage from the Mirror which states that the Soul does not seek God through penitence, meditations, or sacraments of the church (the twenty-ninth error in Vat. lat. 4953 [f. 31v, Guarnieri, 'Il movimento', 660], and the thirtieth error in MS 1647 [f. 220v]; see Speculum CCCM, 243). Once again, Vat. lat. 4953 refutes this with Ad nostrum (where the Mirror extract matches in content with the third error of that decree; see above), but MS 1647 uses Ad abolendam. Where the Mirror famously says that the annihilated Soul is free from the Virtues (the fifth error in Vat. lat. 4953 [f. 29v, Guarnieri, 'Il movimento', 652], the third error in MS 1647 [f. 216r]; see Speculum CCCM, 25), Vat. lat. 4953 again uses Ad nostrum, as the Mirror quotation quite clearly matches the sixth error of that decree (see above). MS 1647 refutes the same quotation first with the author's own inversion of a quotation from Gratian (C. 32 q. 1 c. 9) on vice and virtue, and then relies on several scriptural quotations concerned with virtue, obedience, and the shunning of evil, but makes no mention of any other authority or legislation. Thus in places where Ad nostrum was the most obvious and relevant choice of legislation, the author of the document in MS 1647 makes no use of it.
} 
This makes it extremely likely that Ad nostrum and the Clementines are missing from this text not because of ignorance or oversight, but because they were not yet published, or possibly even written, at the time that this document was originally composed. In other words, the anti-Mirror treatise in MS 1647 may be a fifteenth-century copy of a work which was composed before the publication of the Clementines in 1317, or soon enough after their publication that they were not yet widely available, an interval of perhaps only a year or two. ${ }^{49}$

This possibility carries significant implications for the history of The Mirror of Simple Souls. First and foremost, it would provide a more specific date range for the origins of the Latin translation of the Mirror, something which in the past has been mostly confined to the broad category of 'the fourteenth century'. Recently, Sylvain Piron has suggested the period between 1310-1330. ${ }^{50}$ This is based on his study of the dissemination of the word philocapta, which appears in the Mirror and which originated in the work of the Catalan theologian Ramon Lull between 1273 and 1283. ${ }^{51}$ Piron, like other scholars, also notes that the language of the Latin translation suggests that the original translator would have been French-speaking, but not familiar with the northern Picard dialect in which Marguerite would have originally written. ${ }^{52}$ Based on these two pieces of evidence, Piron theorises that the Latin Mirror may have originated in the Rhône Valley, potentially brought there when the Council of Vienne was laying the groundwork for Ad nostrum. ${ }^{53}$ I agree that southern France seems a likely geographic area of origin, given the translator's difficulties with the dialect and the Mirror's fairly rapid appearance in Italy, and would suggest that the earliest date of origin could be pushed back even further to around 1300, as Piron notes that philocaptus circulated in the south of France at the end of the thirteenth and beginning of the fourteenth centuries, appearing in a treatise by Bernard de Gordon, a doctor in Montpellier, written between the years 1295-1308. ${ }^{54}$ The fact that there seem to have been a large number of Mirror copies circulating early on, during Marguerite's lifetime, makes it possible that a copy could have found its way into the hands of a non-Picard speaking translator prior to the Mirror's

\footnotetext{
${ }^{49}$ Makowski, A Pernicious Sort of Woman, 8.

${ }^{50}$ Sylvain Piron, 'Marguerite, entre les béguines et les maîtres', in Marguerite Porete et le Miroir des simples âmes: Perspectives historiques, philosophique, et littéraires, 88.

51 Ibid., 87.

${ }^{52}$ Ibid., 88. For further comments on the translator struggling with some of the language, see Edmund Colledge, 'The Latin Mirror of Simple Souls: Margaret Porette's 'ultimate accolade'?', in Langland, The Mystics and the Medieval English Religious Tradition: Essays in Honour of S.S. Hussey, ed. Helen Philips (Cambridge, UK: D.S. Brewer, 1990), 180-183, and Michael Sargent, 'Medieval and Modern Readership: The Continental Latin and Italian Tradition,' 86.

53 Piron, 'Marguerite, entre les béguines et les maîtres', 88.

54 Ibid., 87.
} 
condemnation in Paris. ${ }^{55}$ However, while the earliest date of origin is open-ended, the latest possible date can for the first time be set more definitively. If the document in MS 1647 is in fact pre-Clementine, then the origins of the Latin translation can be no later than 1317 . Thus 1300-1317 can be suggested as the newest date range for the origins of the Latin translation. Since the original French text's genesis is usually placed in the last decade of the thirteenth century, this demonstrates a broad dissemination and translation of Marguerite's book early on, and indeed that a Latin version could have circulated alongside the French one during Marguerite's lifetime. This early dissemination is not a new idea in and of itself, but this has mostly been applied to the French version - an early origin for the Latin translation has had far less consideration. Furthermore, if this is a copy of an early document, then it means that the Mirror extracts in it represent - textually, if not physically-some of the earliest surviving text of both the Latin Mirror and of the Mirror in general, matched only by the extracts found in Valenciennes, Bibliothèque municipale, MS 239, thought to date originally from c. $1300 .^{56}$

With such an early date attached to this document, one tantalising question cannot fail to be asked: Is this a copy of the error list, the document detailing the theologians' judgement of The Mirror of Simple Souls, formally given in April of 1310? It is possible that the theologians did not have any knowledge of Marguerite's authorship when they assessed the Mirror, and could have examined it as an anonymous work. ${ }^{57}$ But the judgement made in MS 1647 is very clearly based primarily on legal grounds and not theological ones. Though canon lawyers were consulted on whether Marguerite Porete herself could be condemned as a heretic, there is no record indicating that they were ever consulted on the matter of her book. Additionally, the 'first' and 'fifteenth' errors which are cited in the university theologians' judgment of the Mirror do not correspond to the first and fifteenth errors cited in MS 1647. Furthermore, if the list had been involved in her Parisian trial, then one would expect some

\footnotetext{
55 On multiple copies of the Mirror circulating early on see Marie Bertho, Le miroir des âmes simples et anéanties de Marguerite Porète: une vie blessée d'amour (Paris: Larousse, 1993), 29-32; Field, BAI, 55; and Kocher, Allegories of Love, 32-33. Lerner speculates that there may have been at least four or five copies of the Mirror in existence before Marguerite's arrest in 1308. See Robert E. Lerner, 'New Light on the Mirror of Simple Souls', Speculum 85:1 (2010): 108. Piron states that some of the ways in which theological ideas are expressed in the Latin suggests that the translator would have been a theologically trained cleric. See Piron, 'Marguerite, entre les béguines et les maîtres', 88. For further speculation on whom the original translator may have been, see Trombley, 'The Latin Manuscripts of The Mirror of Simple Souls'.

${ }^{56}$ See Geneviève Hasenohr, 'La tradition du Miroir des simples âmes au XVe siècle', 1347-1366.

${ }^{57}$ See Field, BAI, 127.
} 
indication of this connection in the document itself, given William of Paris's meticulous direction of Marguerite's trial and production of its documentation. ${ }^{58}$

What of the first condemnation, that which was meted out by Guido de Collemezzo at Valenciennes a few years earlier, between 1297 and 1305? Guido was a trained canon lawyer, more than capable of authoring a text like that of MS 1647, and whose own works indicate a man both pedantic and meticulously literal in his critique and approach to even the most straightforward of texts, very similar to the approach taken to the Mirror in the Paduan document. ${ }^{59} \mathrm{He}$, like the pronouncement at the end of this document, ordered the book to be burned, though it is unclear if this condemnation took written form; it merely states that he condemned it 'publicly and solemnly. ${ }^{60}$ But both references in the trial documents to Guido's actions against Marguerite state that after the burning of the Mirror in Valenciennes Guido composed a letter specifically forbidding Marguerite from recomposing or redistributing her work, indicating that, though perhaps he did not deal with her face-to-face, Guido was certainly aware of Marguerite's identity and her authorship of the Mirror ${ }^{61}$ This conflicts with MS 1647, which clearly has no knowledge of the Mirror's authorship or its origins, as is evident in its use of the term apocryphus and its repeated reference to the author as a male. It is possible that Guido himself did not read and assess the book; like William of Paris with the theologians, he could have had the work assessed—without providing any information on its authorship — by someone else, a canonist who set his opinion down in writing and gave it to Guido. Though the pronouncement at the end of MS 1647 calls for both author and book to be burned-whereas it is clear that Marguerite walked away from this first incident unharmed - this would not necessarily mean that Guido would have taken this suggestion on board. He could have felt that, if Marguerite recanted her views - and her escape from the flames this time shows that she probably did - then merely burning the book would have sufficed. ${ }^{62}$ But this theory, too, has many weak points. If Guido had given the Mirror to a canonist for assessment, even without imparting any knowledge of the author's identity, it seems unlikely that the assessment would state that the book was apocryphus. ${ }^{63}$ Even without explicitly mentioning Marguerite, Guido would surely have indicated that this

\footnotetext{
${ }^{58}$ On William of Paris's handling of Marguerite's case, see Field, BAI, 85-172.

${ }^{59}$ See Field, BAI, 43-44, and Sean L. Field, 'Guido of Collemezzo's Extracci de Dictis Bernardi et quibusdam aliis Super Evangelio "Missus est Angelus Gabriel”" in Mediaeval Studies 74 (2012): 143-162 for a discussion of Guido's career and of his intellectual approach to texts.

${ }^{60}$ Verdeyen, 'Le process', 78, and Field, BAI, 225.

${ }^{61}$ Field, BAI, 44.

${ }^{62}$ For a discussion of Marguerite's apparent cooperation in her first clash with ecclesiastical authorities, see Field, BAI, 45.

${ }^{63}$ I thank Sean Field for this point. Personal correspondence.
} 
was not a random work that had merely fallen into his hands. In fact, the Mirror's apocryphal nature is the very first point noted against it, giving the impression that the author of this document was encountering the Mirror in a context unconnected with any specific person or situation. Additionally, as noted above, the author's tone suggests he was acting on his own initiative, rather than on the orders of another.

If not associated with Marguerite's trial, from where did this document come? There is very little evidence to go on at this juncture, and thus only the barest of speculations can be made. The author's lack of awareness regarding the Mirror's origins and inquisitorial treatment suggests that the document was first written outside the areas surrounding Valenciennes and Paris, where Marguerite's two trials and execution would probably have been known. But if the document were written before Marguerite's Parisian trial took place, then the Valenciennes area would stand as the main area of exclusion. Needless to say, this still leaves a vast geographic spread, and there is nothing in MS 1647 to indicate where the exemplar for this document came from. Though its fifteenth-century form was almost certainly copied in Bologna, this does not necessarily mean it originated there, or had even been there for long before coming to the attention of Giacomo de Zocchi, as the university attracted a large number of international scholars who could have brought it with them at any time. For now, its origins remain a mystery.

Mysteries aside, MS 1647 opens up exciting new avenues of investigation for scholars of the Mirror. Its dual historical contexts - origins in the early fourteenth century, and copying in the early fifteenth - allow for new perspectives on the Mirror in both its earliest years and its post-condemnation circulation. It provides a unique glimpse into the thought process of a cleric who was genuinely alarmed by what was contained in its pages, and who expended a great deal of emotional and intellectual energy in denouncing it. Furthermore, this cleric was contemporary - or nearly so-with Marguerite herself. This demonstrates that the Mirror, around the same time as the events surrounding Marguerite's trial and execution, but entirely separate from them, could receive the same judgment as that which Guido of Collemezzo and the Parisian theologians meted out to it. This reveals that to some, the Mirror could stand on its own as a dangerous heretical text, unconnected to any specific author. Its later copying and possession by Giacomo de Zocchi adds another facet to the Mirror's colourful fifteenth-century career as well, and stands as another example of the interest in - and concern over-the Mirror in Northern Italy. Finally and crucially, MS 1647 provides a new terminus ante quem for the origins of the Latin translation and adds to the corpus of surviving Latin Mirror text. This is a significant step forward in our knowledge of 
the Latin tradition, a step that brings the Latin closer in time to Marguerite herself. Further study of MS 1647 will no doubt continue to yield interesting results. Thus, by remembering this forgotten manuscript, we can begin to unravel at least a few of the many mysteries which surround The Mirror of Simple Souls. 